\title{
Merging the old with the new: a cybermedicine marriage for oncology interactions with traditional herbal therapies and complementary medicines
}

\author{
Kevin Yi-Lwern Yap ${ }^{1, *}$, Ken Juin Lim $^{2}$ \\ ${ }^{1}$ Institute of Digital Healthcare, WMG, University of Warwick, International Digital Laboratory, Coventry, CV4 7AL, United \\ Kingdom; ${ }^{2}$ Department of Pharmacy, Faculty of Science, National University of Singapore, Block S4, 18 Science Drive 4, Singapore \\ 117543, Singapore
}

\begin{abstract}
An oncology-specific database called OncoRx (http://bit.ly/cancerRx) was previously set up in cyberspace to aid clinicians in identifying interactions of anticancer drugs (ACDs) and chemotherapy regimens with traditional Chinese medicines (TCMs) and complementary and alternative medicines (CAMs). Since then, users have requested the drug-CAM interactions (DCIs) of 5 specific CAMs (cranberry, melatonin, co-enzyme Q10, huachansu, reishi mushroom) to be updated in the database. Pharmacokinetic properties (metabolism, enzyme induction/inhibition, elimination), TCM properties and DCIs of each CAM were collated with 117 ACDs using 9 hardcopy compendia and online databases as resources. Additionally, individual ACDs and CAMs were used as keywords for PubMed searches in combination with the terms 'anticancer drugs', 'drug interactions', 'herb-drug/drug-herb interactions', 'pharmacokinetic interactions' and 'pharmacodynamic interactions'. DCI parameters consisted of interaction effects, evidence summaries, proposed management plans and alternative non-interacting CAMs, together with relevant citations and update dates of the DCIs. OncoRx is also used as a case to introduce the "Four Pharmaco-cybernetic Maxims" of quality, quantity, relationship and manner to developers of digital healthcare tools. Its role in Hayne's " $5 \mathrm{~S}$ " hierarchy of research evidence is also presented. OncoRx is meant to complement existing DCI resources for clinicians and alternative medicine practitioners as an additional drug information resource that provides evidence-based DCI information for ACD-CAM interactions.
\end{abstract}

Keywords traditional Chinese medicines, complementary medicines, anticancer drugs, drug-CAM interactions, digital healthcare, pharmaco-cybernetic maxims

\section{INTRODUCTION}

The advent of the internet has led to healthcare professionals and patients being more well-informed about medications and diseases through health-related information that can be accessed online. In Europe, it is estimated that the percentage of the population that has used the internet for seeking health information increased from $43 \%$ in 2005 to $52 \%$ in 2007 (Kummervold et al., 2008) while in the US population, out of the $40 \%$ that used the internet for health information, one-third indicated that this information affected their decision making (Baker et al., 2003). Cancer is one of the top few diseases that people seek information online (Shim, 2008). Cancer patients tend to use the internet to seek information regarding treatment therapies, find experiences and/or support from other cancer survivors, help interpret consultations, and even source for second opinions (Ziebland et al., 2004). However, several drug-related problems have arisen in this cybermedicine age (Yap et al., 2009a). For example, some patients may retrieve erroneous information from the internet or misinterpret generalized information about cancer therapies that is not

*Correspondence: Kevin Yi-Lwern Yap

E-mail: kevinyap.ehealth@gmail.com

Received January 20, 2012; Accepted May 22, 2012; Published May

31,2012

doi: http://dx.doi.org/10.5667/tang.2012.0004

(C)2012 by Association of Humanitas Medicine

TANG / www.e-tang.org applicable to them. Also, some patients may resort to sourcing for cheaper alternatives to their anticancer drugs (ACDs) online in the attempt to find the best deals for their chemotherapies.

The use of complementary and alternative medicines (CAMs), including traditional Chinese medicinal (TCM) herbs/herbal therapies, is common among cancer patients. Studies have shown that between $9 \%$ and $91 \%$ of cancer patients in the USA use some form of CAMs after cancer diagnosis (White, 2002), and this usage has increased over the years (DiGianni et al., 2002; Nahleh and Tabbara, 2003; Yates et al., 2005). Besides being used as an adjunct for cancer treatment, many patients also use CAMs for supportive care, such as to boost their immunity and to relieve the adverse effects of fatigue, nausea, vomiting, alopecia and pain (Mansky and Wallerstedt, 2006; Tascilar et al., 2006). In TCM theory, cancer is a result of imbalances between internal conditions of the body and exogenous pathogenic factors such as accumulated toxins, heat and blood stasis (Hsiao and Liu, 2010). One of the basic principles in TCM's approach to cancer therapy is Fu-zheng therapy, which is used to enhance the body's defense mechanism (Macek, 1984). Another principle in TCM involves qi, otherwise known as "vital energy". Qi is fundamental to the maintenance of the body's life activities, with functions in warming, defense, homeostasis and the circulation of blood and bodily fluids (Tan et al., 2008). It is believed that the weakening of qi depresses an individual's immunity and thus increases one's susceptibility to infection 
and cancer progression (Wong et al., 2001). Some herbs, such as the medicinal mushroom Ganoderma, strengthen qi, thereby resulting in improved immune functions and anticancer activities (Wong et al., 2001). On the other hand, CAMs with anticancer effects, including TCM herbs and herbal extracts, can also be categorized based on their different mechanisms of action (Hsiao and Liu, 2010). For example, one of the active constituents of huachansu (an extract from toad skin venom secretions), known as bufalin, induces apoptosis and suppresses the proliferation of various cancer cell lines (Jiang et al., 2010; Takai et al., 2008; Yu et al., 2008; Yun et al., 2009).

Many patients consume CAMs without their physician's knowledge and may not be aware that adverse effects from drug-CAM interactions (DCIs) can potentially occur when used concurrently with ACDs (Oldendick et al., 2000). DCIs can lead to increased toxicities, subtherapeutic effects or potentiated adverse effects, resulting in undesirable patient outcomes; some of which can be significant, for example, myelosuppression, liver toxicity or tumor growth stimulation (Sparreboom et al., 2004). As anticancer therapies often involve multiple-drug regimens, the risk of DCIs is compounded. There is abundant information on cancer treatment strategies on the internet (Yap et al., 2009b), but little on DCI information, particularly for TCMs. Conventional drug resources that oncology clinicians use provide detailed information for well-established herbs such as ginseng or St. John's wort, but not for all herbs (British Medical Association and Pharmaceutical Society of Great Britain, 2007; Gerstner Jr., 2008; Jellin and Gregory, 2007; Lacy et al., 2007-2008; Thomson Healthcare, n.d.). On the other hand, TCM resources are limited in the DCI data for clinician use (e-MS Inc., 2004; Rootdown LLC, 2008); thus emphasizing the need for an appropriate resource for oncology clinicians to identify possible DCIs between CAMs and chemotherapies, so that they can make timely interventions to achieve the best therapeutic outcomes for patients.

To aid clinicians with identifying DCIs for ACDs and chemotherapy regimens, an oncology-specific database called OncoRx (http://bit.ly/cancerRx) was previously set up in cyberspace (Yap et al., 2010c). This database provided information on DCIs between 117 ACDs and 166 CAMs. To date, OncoRx has users from a wide variety of disciplines ranging from oncologists and oncology pharmacists, to researchers and naturopaths across different countries. There is a need to keep the database updated with more CAMs and DCIs to cater towards its users. Specifically, several users have requested the DCIs of 5 CAMs to be added to the database cranberry, melatonin, co-enzyme Q10 (Co-Q10), huachansu and reishi mushroom (lingzhi). The objective of this paper is to use OncoRx and the DCIs detected with these 5 herbs to illustrate how digital healthcare tools can add value to clinical practices in this cybermedicine era. The role of OncoRx as an example of an evidence-based resource is discussed together with several design principles that developers of digital healthcare tools are encouraged to follow.

\section{MATERALS AND METHODS}

The list of 5 CAMs (cranberry, melatonin, Co-Q10, huachansu,
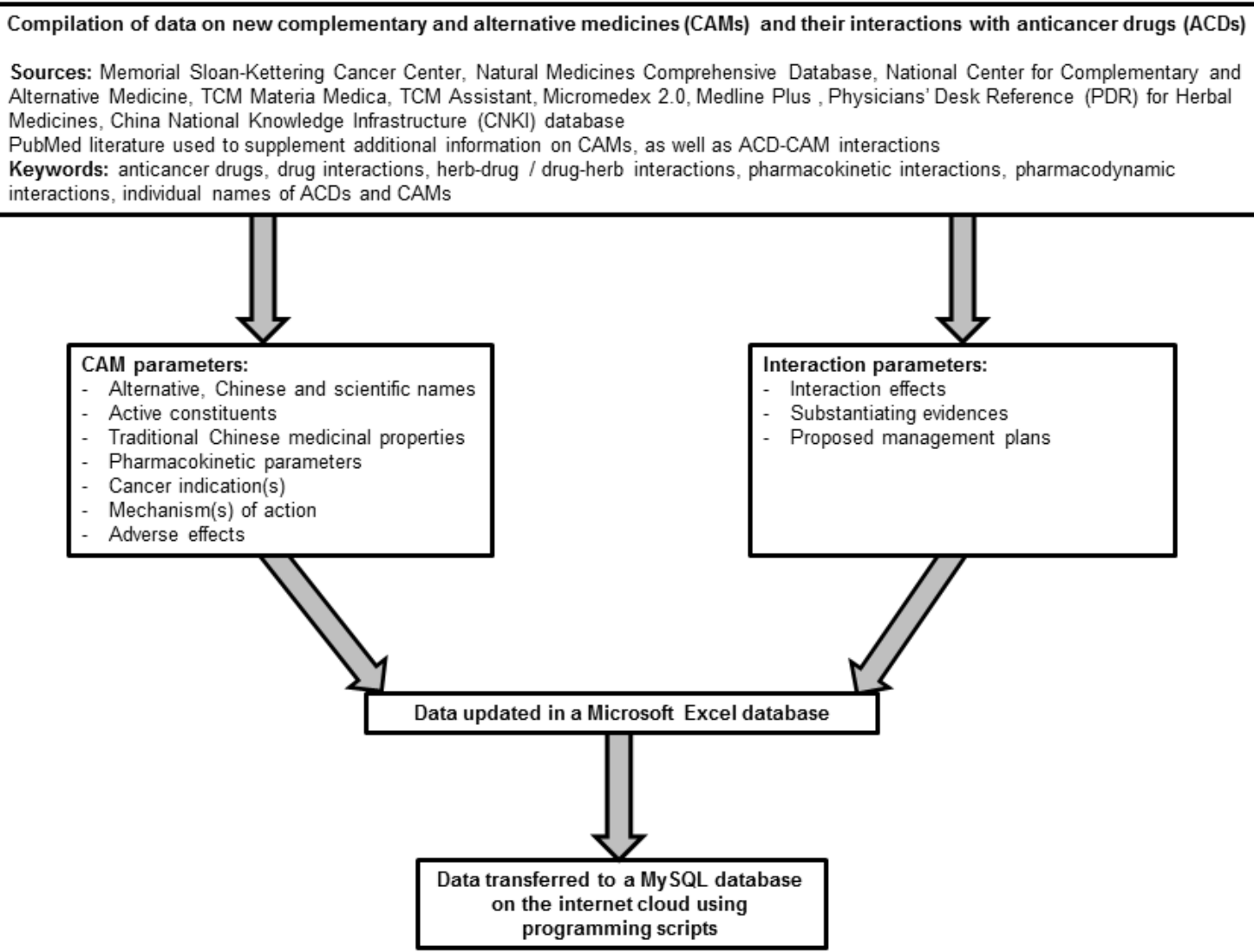

Fig. 1. Flowchart showing methodology of updating the OncoRx database. 


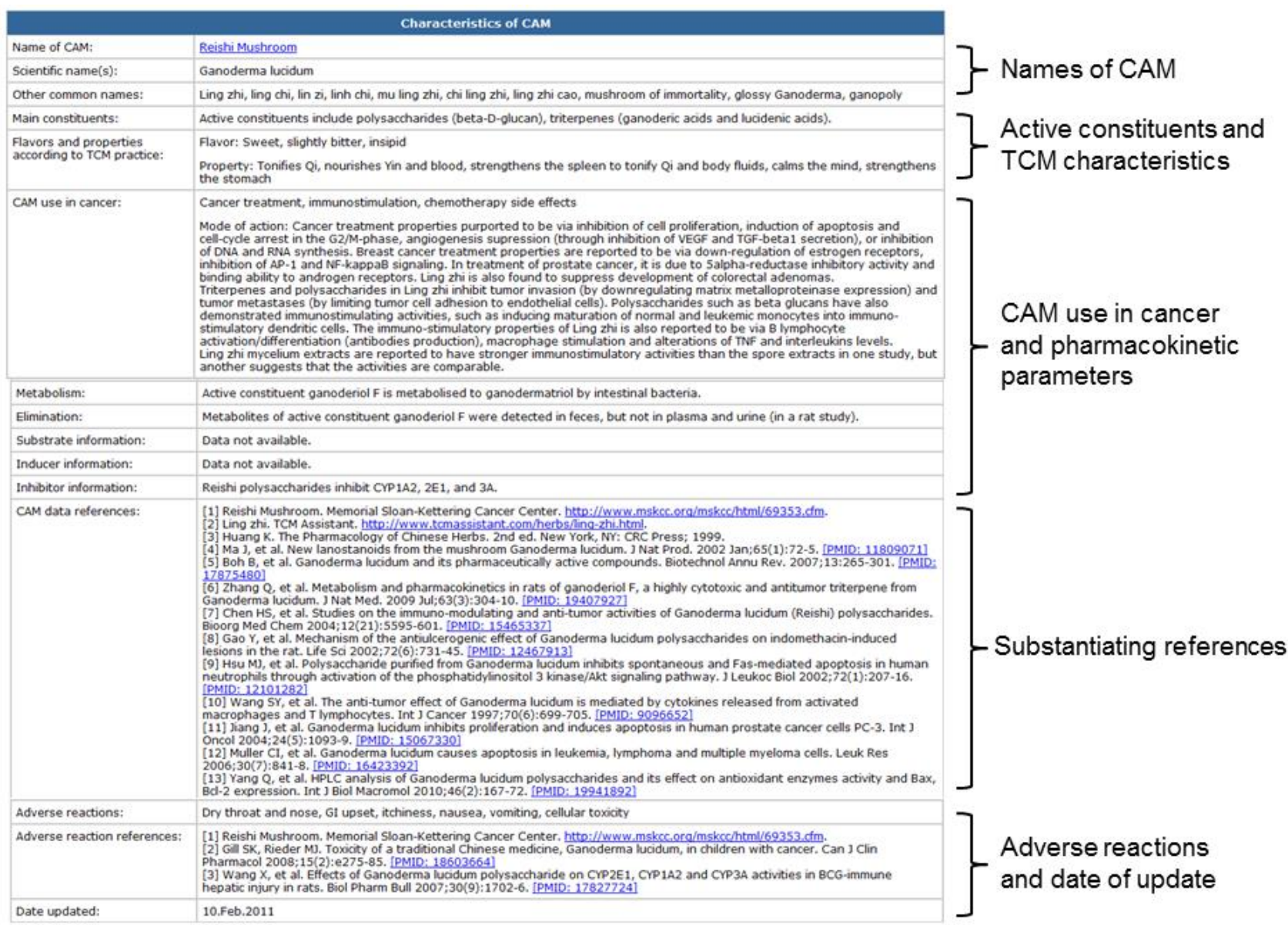

Fig. 2. Screenshot of OncoRx search between reishi mushroom and dexamethasone, showing the section on CAM characteristics.

reishi mushroom) was determined before data on their pharmacokinetic properties and characteristics were compiled. Additionally, the DCIs of each CAM were collated with the 117 ACDs in the database. Nine hardcopy compendia and online databases were used as resources. These included the databases from Memorial Sloan-Kettering Cancer Center (Gerstner Jr., 2008), Natural Medicines Comprehensive Database (Jellin and Gregory, 2007), National Center for Complementary and Alternative Medicine (National Institutes of Health and National Center for Complementary and Alternative Medicine), TCM Materia Medica (Raymond, 2000), TCM Assistant (e-MS Inc., 2004), Micromedex 2.0 (Thomson Healthcare, n.d.), Medline Plus (National Institutes of Health, 1995) and Physicians' Desk Reference for Herbal Medicines (Gruenwald et al., 2007). An additional database, the China National Knowledge Infrastructure (CNKI) database (Tsinghua Tongfang Knowledge Network Technology Co. Ltd., 2006) was also used for compiling information on the herbal therapies huachansu and reishi mushroom. Data compiled included the Chinese, scientific and alternative names of the CAMs, their active constituents, TCM properties (if applicable), pharmacokinetic parameters, cancer indications and mechanisms of action, as well as adverse effects. Published literature from PubMed was used to supplement additional information regarding the CAMs, as well as to search for DCIs with the ACDs. The common and scientific names of the CAMs (i.e. cranberry [Vaccinium macrocarpon], melatonin, co-enzyme Q10 [ubiquinone], huachansu [Bufo gargarizans] and reishi mushroom [Ganoderma lucidum, lingzhi]) were used as keywords for the searches in combination with the terms 'anticancer drugs', 'drug interactions', 'herb-drug/drug-herb interactions', 'pharmacokinetic interactions' and

TANG / www.e-tang.org 'pharmacodynamic interactions', as well as the individual ACD names and their pharmacological categories (Table 1). DCI parameters consisted of interaction effects, substantiating evidences and proposed management plans. All the data were first updated in Microsoft Excel, and then transferred to a MySQL (structured query language) database in the internet cloud. Fig. 1 shows a summary flowchart of the methodology for updating the database.

\section{RESULTS}

\section{Database structure}

When users search for a DCI in the OncoRx database, for example, reishi mushroom and dexamethasone (a steroid commonly used for the control of chemotherapy-induced nausea and vomiting) (Chan et al., 2011), they will be shown a display of their selections of ACD and CAM, followed by 3 separate sections: (i) the pharmacokinetic parameters of the ACD, (ii) the characteristics of the CAM, and (iii) the detected DCI. In terms of the CAM characteristics (Fig. 2), information shown to the users includes the scientific and other common names of the CAM, in this case, Ganoderma lucidum and lingzhi respectively. The main active constituents (beta-D-glucan, ganoderic and lucidenic acids) are also displayed together with its TCM characteristics (sweet, slightly bitter; tonifies Qi, nourishes the Yin and blood). Additionally, its intended use in cancer (cancer treatment and immunostimulation), metabolism and enzyme induction and/or inhibition effects, as well as elimination information is provided together with a reference list and hyperlinks. A list of adverse reactions is also provided. 


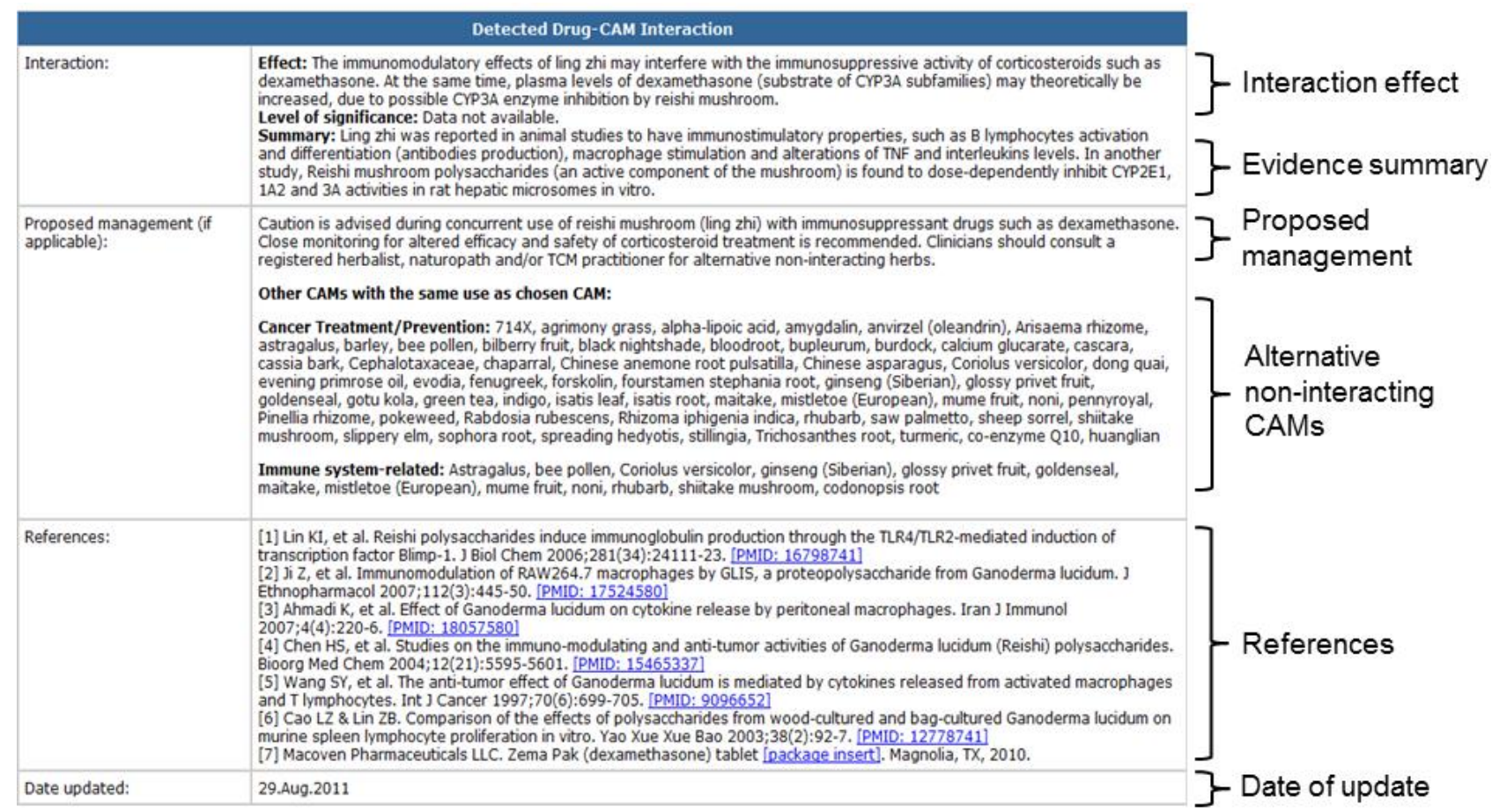

Fig. 3. Screenshot of OncoRx search between reishi mushroom and dexamethasone, showing the section on drug-CAM interactions.

The DCI parameters of the database (Fig. 3) include the identified DCI effect, an evidence summary of the DCI with relevant references, as well as a proposed management plan. In this example, a pharmacokinetic and pharmacodynamic interaction is detected - plasma dexamethasone levels may be increased due to cytochrome P450 (CYP) 3A isozyme inhibition, and the immunostimulatory properties of reishi mushroom may interfere with the immunosuppressive effects of dexamethasone. Close monitoring of altered efficacy and safety of corticosteroidal treatment is advised and clinicians should consult a herbalist, naturopath and/or TCM practitioner for alternative non-interacting herbs. A list of CAMs within the cancer treatment/prevention and immune-system-related categories that the database does not detect any interactions with is also provided. An additional feature that has been added to OncoRx is the update date of the DCI, which is intended to show how current the information is to its users.

\section{CAM interactions with anticancer drugs Co-enzyme Q10 (Co-Q10)}

Co-Q10, also known as ubiquinone, is generally used for cancer prevention or treatment due to its free radical scavenging and membrane stabilizing properties (Memorial Sloan-Kettering Cancer Center, 2011). Other non-cancer-related indications include improvements of heart function in heart failure (Belardinelli et al., 2006), and the treatment of hypertension (Rosenfeldt et al., 2007) and cyclic vomiting syndrome (Boles et al., 2010). Co-Q10 was found to decrease the cardiotoxicity caused by anthracyclines (Table 1), such as daunorubicin and doxorubicin (Conklin, 2005), in small-scale human studies which showed smaller reductions in cardiac functions, the absence of QRS depression and QT prolongation, and an increased cumulative tolerable dose of doxorubicin (Conklin, 2005; Tsubaki et al., 1984). However, the long-term effects of combination therapy on cardiac functions were not measured. The mechanism of cardio-protection was suggested to be due to its ability to prevent the anthracyclines from being reduced to their semiquinone forms, which cause high oxidative stress in cardiac cells (Conklin, 2005). Evidence of its protective effect

TANG / www.e-tang.org on anthracycline-induced cardiotoxicity was also demonstrated in animals (Combs et al., 1977; Shinozawa et al., 1996). However, in another study on mice pretreated with co-Q10, the concentration of the major metabolite of doxorubicin (aglycone I) was higher in the co-Q10 group compared to saline controls (Shinozawa et al., 1991). The authors advised caution over concurrent administration with co-Q10. As such, caution is advised in patients concurrently on co-Q10 and anthracyclines since the long-term effects of cardio-protection are still not well established. Patients should still be monitored for signs and symptoms of cardiotoxicity, and an alternative non-interacting CAM should be considered with the help of a registered herbalist, naturopath or an alternative medicine practitioner.

\section{Cranberry}

Cranberry (Vaccinium macrocarpon) is commonly used for the prevention of urinary tract infections in women (Stothers, 2002). It is also known to be effective in suppressing Helicobacter pylori infections (Zhang et al., 2005). The anthocyanins, proanthocyanidins, and flavonol glycoside fractions within cranberry juice have been suggested to have anticancer properties (Ferguson et al., 2004; Ferguson et al., 2006; Neto et al., 2008; Seeram et al., 2004), with its extracts showing antiproliferative effects in vitro (Sun and Hai Liu, 2006).

Cranberry can inhibit CYP2C9 and 3A4, therefore it can theoretically interact with ACDs that are substrates of these isozymes (Table 1). In vitro studies have shown cranberry juice to inhibit CYP2C9-mediated metabolism of phenytoin (Ushijima et al., 2009a). Furthermore, the international normalized ratios of warfarin, another CYP2C9 substrate, were shown to be elevated in numerous case reports (Grant, 2004; Griffiths et al., 2008; Hamann et al., 2011; Paeng et al., 2007; Suvarna et al., 2003; Welch and Forster, 2007). The CYP3A inhibition activity of cranberry juice was demonstrated in human and animal studies using midazolam and nifedipine probes (Ngo et al., 2009). However, there is conflicting evidence on the enzyme inhibiting potential of this CAM. Pharmacokinetic studies showed that cranberry did not inhibit CYP1A2, 2C9, or 3A4 in vitro and in vivo (Lilja et al., 2007; 
Ushijima et al., 2009b). In another clinical study involving 14 healthy volunteers, cranberry juice did not significantly reduce CYP2C9-mediated metabolism of flurbiprofen (Greenblatt et al., 2006). Nonetheless, caution is advised in patients who are concurrently on cranberry juice and ACDs that are CYP1A2, $2 \mathrm{C} 9$ or $3 \mathrm{~A} 4$ substrates. Such patients should be monitored for increased plasma ACD levels and signs and symptoms of ACD-associated toxicities. Dosage adjustments should be carried out where appropriate and clinicians should refer to the ACD package inserts for more detailed dosing information.

\section{Huachansu}

Huachansu is an extract derived from skin venom secretions of toads (Bufo gargarizans). Its active constituents consist of indole alkaloids and cardiac glycosides (bufalin, resibufogenin, cinobufagin), which are thought to be responsible for its anticancer properties (Meng et al., 2009; Yang et al., 2006). The mechanisms of action for its anticancer activity include the induction of apoptosis, inhibition of cell proliferation and cancer angiogenesis, disruption of the cell cycle and immunoregulatory effects (Qi et al., 2011). In addition, huachansu has hepatoprotective effects as well (Qin et al., 2008).

Numerous studies have shown huachansu's anticancer activities through its synergistic actions with ACDs. In vitro and in vivo studies showed that huachansu and its bufalin and cinobufacin constituents act by either inhibiting cell and tumor proliferation, angiogenesis, or inducing apoptosis. These synergistic effects occurred in combination with cisplatin (Hashimoto et al., 1997), etoposide (Zhang et al., 2007), fluorouracil (Han et al., 2006), gemcitabine (Yang et al., 2008), paclitaxel (Xu, 2009) and vinorelbine (Wu et al., 2004).

Bufalin, an active constituent in huachansu, inhibited CYP3A4 activity both in vitro and in vivo ( $\mathrm{Li}$ et al., 2009). Significant increases in areas under the concentration-time curves and half-lives, as well as decreases in clearance and formation of metabolites, were observed after administration of midazolam in Wistar rats. Therefore, this CAM could interact with ACDs that are CYP3A4 substrates, leading to increased plasma levels of these drugs (Table 1). These include the alkylating agents, antimetabolites, antimicrotubules, corticosteroids, hormone agonists/antagonists, topoisomerase inhibitors and the tyrosine kinase inhibitors, among others. Patients concurrently on huachansu and these agents should be monitored for increased plasma ACD levels, and dosage adjustments carried out when necessary. In particular, clinicians should refer to the package inserts of ACDs such as erlotinib, ixabepilone and trabectedin for specific dosing instructions.

\section{Melatonin}

Melatonin is commonly used as a supplement to treat jet lag and insomnia (Brzezinski, 1997). However, it also has anticancer activities against mammary tumors (González et al., 2010), hepatic (Martín-Renedo et al., 2008) and pancreatic carcinomas (Leja-Szpak et al., 2010) based on several in vitro and animal studies. The mechanisms of action for its anticancer effects are suggested to be due to its pro-apoptotic (Leja-Szpak et al., 2010; Trubiani et al., 2005), oncostatic (Ortíz-López et al., 2009) and antiangiogenic activities (Park et al., 2009). In addition, it has anti-cachectic, anti-asthenic and thrombopoietic activities, as well as improving cardiotoxicity and neurotoxicity profiles (Lissoni, 2002; Lissoni et al., 1999; Lissoni et al., 1997), thus making it potentially useful for the supportive care of cancer patients.

The immunostimulatory properties of melatonin can be a double-edged sword in cancer treatment. While it can exhibit some benefits with certain ACD therapies, such as cyclophosphamide, as a result of increased interleukin-2 production and enhanced T-helper cell activity (Caroleo et al., 1992; Zupancic et al., 2009); these same properties can also interfere with the immunosuppressive activities of the corticosteroids (Haldar et al., 2004), which in turn may render chemotherapy less effective (Table 1). These DCIs are of high severity (Jellin and Gregory, 2007) and the effects may be more pronounced when this CAM is used together with interleukin-2 (Lissoni et al., 1993). As such, melatonin should not be used concurrently with corticosteroids. However, if avoidance is not possible, monitoring for altered efficacy and safety of corticosteroid therapy should be carried out

Table 1. Interactions between complementary and alternative medicines (CAMs) and anticancer drugs (ACDs)

\begin{tabular}{|c|c|c|c|c|}
\hline CAM & Interaction with ACDs & $\begin{array}{l}\text { Interaction effect and } \\
\text { mechanism }\end{array}$ & Evidence & Proposed management \\
\hline $\begin{array}{l}\text { Co-enzyme } \\
\text { Q10 }\end{array}$ & $\begin{array}{l}\text { Daunorubicin, doxorubicin } \\
\text { (Combs et al., 1977; } \\
\text { Conklin, 2005; Greenberg } \\
\text { and Frishman, 1990; } \\
\text { Shinozawa et al., 1991; } \\
\text { Shinozawa et al., 1996) }\end{array}$ & $\begin{array}{l}\text { Co-enzyme Q10 may } \\
\text { decrease } \\
\text { anthracycline-induced } \\
\text { cardiotoxicity due to its } \\
\text { free radical scavenging } \\
\text { properties, and its ability to } \\
\text { prevent the ACDs from } \\
\text { being reduced to their } \\
\text { semiquinone forms, which } \\
\text { cause oxidative damage to } \\
\text { mitochondrial DNA of } \\
\text { cardiomyocytes. }\end{array}$ & $\begin{array}{l}\text { Cardio-protective effects of } \\
\text { co-enzyme Q10 were found in } \\
\text { both animal and human } \\
\text { studies. However, one animal } \\
\text { study also showed conflicting } \\
\text { results. Small-scale human } \\
\text { studies showed smaller } \\
\text { reductions in cardiac function, } \\
\text { absence of QRS depression } \\
\text { and QT prolongation, and an } \\
\text { increased cumulative tolerable } \\
\text { dose of doxorubicin. However, } \\
\text { long-term cardio-protective } \\
\text { effects not } \\
\text { well-established. In contrast, a } \\
\text { study of mice pretreated with } \\
\text { co-enzyme Q10 showed that } \\
\text { the concentrations of aglycone } \\
\text { I (major metabolite of } \\
\text { doxorubicin) in the kidney and } \\
\text { heart were significantly higher } \\
\text { in the co-enzyme Q10 group } \\
\text { compared to the saline } \\
\text { controls. }\end{array}$ & $\begin{array}{l}\text { Caution is advised. Patients } \\
\text { concurrently on co-enzyme Q10 } \\
\text { and anthracyclines should be } \\
\text { closely monitored for } \\
\text { anthracycline-induced } \\
\text { cardiotoxicities. A suitable } \\
\text { non-interacting alternative } \\
\text { should be considered with the } \\
\text { help of a registered herbalist, } \\
\text { naturopath and/or TCM } \\
\text { practitioner. }\end{array}$ \\
\hline Cranberry & Capecitabine, tegafur (Clarke & Increased plasma & Contradictory evidence exists. & Caution is advised. Patients \\
\hline
\end{tabular}




\begin{tabular}{|c|c|c|c|c|}
\hline & $\begin{array}{l}\text { et al., 2010; Grant, 2004; } \\
\text { Greenblatt et al., 2006; } \\
\text { Griffiths et al., 2008; Lilja et } \\
\text { al., 2007; Paeng et al., 2007; } \\
\text { Suvarna et al., 2003; } \\
\text { Ushijima et al., 2009a; } \\
\text { Welch and Forster, 2007; } \\
\text { Zikria et al., 2010) }\end{array}$ & $\begin{array}{l}\text { levels due to inhibition of } \\
\text { CYP2C9 by cranberry. }\end{array}$ & $\begin{array}{l}\text { An in vitro study suggested } \\
\text { that cranberry juice might } \\
\text { inhibit CYP2C9-mediated } \\
\text { metabolism of phenytoin. } \\
\text { Furthermore, cranberry juice } \\
\text { was reported to elevate the } \\
\text { international normalized ratios } \\
\text { of patients on warfarin } \\
\text { (CYP2C9 substrate) in various } \\
\text { case reports. Additionally, a } \\
\text { man concurrently on warfarin, } \\
\text { phenytoin and digoxin died } \\
\text { from gastrointestinal and } \\
\text { pericardial hemorrhaging due } \\
\text { to an interaction with } \\
\text { cranberry juice. } \\
\text { In contrast, an in vivo study } \\
\text { involving warfarin, tizanidine } \\
\text { and midazolam probes showed } \\
\text { that cranberry juice did not } \\
\text { inhibit CYP2C9, } 1 \mathrm{~A} 2 \text { or } 3 \mathrm{~A} 4 . \\
\text { In another study of } 14 \text { healthy } \\
\text { volunteers, cranberry juice did } \\
\text { not significantly reduce } \\
\text { CYP2C9-mediated } \\
\text { metabolism of flurbiprofen. }\end{array}$ & $\begin{array}{l}\text { taking these agents concurrently } \\
\text { should be carefully monitored } \\
\text { for increased plasma ACD } \\
\text { levels. Dosage adjustments } \\
\text { should be carried out when } \\
\text { necessary. } \\
\text { In addition, patients concurrently } \\
\text { on capecitabine and cranberry } \\
\text { juice should be monitored for } \\
\text { capecitabine toxicity and doses } \\
\text { adjusted accordingly based on } \\
\text { patient's tolerance level. } \\
\text { Clinicians are referred to the } \\
\text { product information for further } \\
\text { information on dosage } \\
\text { adjustments for capecitabine. }\end{array}$ \\
\hline Cranberry & $\begin{array}{l}\text { Alkylating agents } \\
\text { Cyclophosphamide, } \\
\text { ifosfamide } \\
\text { Antimicrotubules } \\
\text { Paclitaxel } \\
\text { Hormone } \\
\text { antagonists } \\
\text { Tamoxifen, norethisterone } \\
\text { Tyrosine kinase inhibitors } \\
\text { Bortezomib, imatinib } \\
\text { Retinoids: Tretinoin (Clarke } \\
\text { et al., 2010; Grant, 2004; } \\
\text { Greenblatt et al., 2006; } \\
\text { Griffiths et al., 2008; Lilja et } \\
\text { al., 2007; Ngo et al., 2009; } \\
\text { Paeng et al., 2007; Roxane } \\
\text { Laboratories Inc., 2007; } \\
\text { Suvarna et al., 2003; Uesawa } \\
\text { and Mohri, 2006; Ushijima } \\
\text { et al., 2009a; Welch and } \\
\text { Forster, 2007; Zikria et al., } \\
\text { 2010) }\end{array}$ & $\begin{array}{l}\text { Increased plasma ACD } \\
\text { levels due to inhibition of } \\
\text { CYP2C9 and 3A4 by } \\
\text { cranberry. }\end{array}$ & $\begin{array}{l}\text { Contradictory evidence exists. } \\
\text { Cranberry juice inhibited } \\
\text { enteric, but not hepatic, } \\
\text { CYP3A-mediated metabolism } \\
\text { in studies using midazolam } \\
\text { (humans) and nifedipine } \\
\text { (animals) as probes. In } \\
\text { addition, an in vitro study } \\
\text { suggested that cranberry juice } \\
\text { might inhibit } \\
\text { CYP2C9-mediated phenytoin. } \\
\text { metabolism of phen } \\
\text { Furthermore, cranberry juice } \\
\text { was reported to elevate the } \\
\text { international normalized ratios } \\
\text { of patients on warfarin } \\
\text { (CYP2C9 substrate) in various } \\
\text { case reports. Additionally, a } \\
\text { man concurrently on warfarin, } \\
\text { phenytoin and digoxin died } \\
\text { from gastrointestinal and } \\
\text { pericardial hemorrhaging due } \\
\text { to an interaction with } \\
\text { cranberry. } \\
\text { In contrast, an in vivo study } \\
\text { involving warfarin, tizanidine } \\
\text { and midazolam probes showed } \\
\text { that cranberry juice did not } \\
\text { inhibit CYP2C9, 1A2 or } 3 \mathrm{~A} 4 \text {. } \\
\text { In another study of } 14 \text { healthy } \\
\text { volunteers, cranberry juice did } \\
\text { not significantly reduce } \\
\text { CYP2C9-mediated } \\
\text { metabolism of flurbiprofen. }\end{array}$ & $\begin{array}{l}\text { Caution is advised. Patients } \\
\text { should be carefully monitored } \\
\text { for increased plasma ACD levels } \\
\text { and any adverse effects or } \\
\text { toxicities. Dosage adjustments } \\
\text { should be carried out where } \\
\text { appropriate. } \\
\text { The product information of } \\
\text { cyclophosphamide also } \\
\text { recommends regular monitoring } \\
\text { of the patient's hematological } \\
\text { profile (particularly neutrophil } \\
\text { and platelet counts) to determine } \\
\text { the degree of hematopoietic } \\
\text { suppression. }\end{array}$ \\
\hline Cranberry & 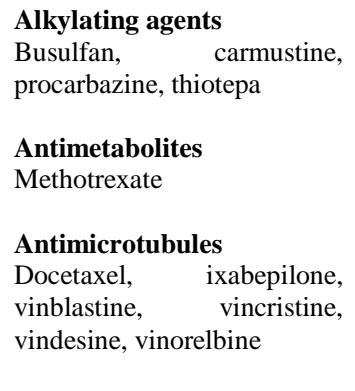 & $\begin{array}{l}\text { Increased plasma ACD } \\
\text { levels due to inhibition of } \\
\text { CYP3A4 by cranberry. }\end{array}$ & $\begin{array}{l}\text { Contradictory evidence exists. } \\
\text { Cranberry juice inhibited } \\
\text { enteric, but not hepatic, } \\
\text { CYP3A-mediated metabolism } \\
\text { in studies using midazolam } \\
\text { (humans) and nifedipine } \\
\text { (animals) as probes. } \\
\text { In contrast, an in vivo study } \\
\text { involving warfarin, tizanidine } \\
\text { and midazolam probes showed } \\
\text { that cranberry juice did not } \\
\text { inhibit CYP2C9, } 1 \mathrm{~A} 2 \text { or } 3 \mathrm{~A} 4 \text {. }\end{array}$ & $\begin{array}{l}\text { Caution is advised. Patients } \\
\text { should be carefully monitored } \\
\text { for increased plasma ACD levels } \\
\text { and any adverse effects or } \\
\text { toxicities. Dosage adjustments } \\
\text { should be carried out where } \\
\text { appropriate. } \\
\text { In addition, the following should } \\
\text { be taken into account with these } \\
\text { ACDs: } \\
\text { (a) Erlotinib: Doses should be }\end{array}$ \\
\hline
\end{tabular}




\begin{tabular}{|c|c|c|c|c|}
\hline & 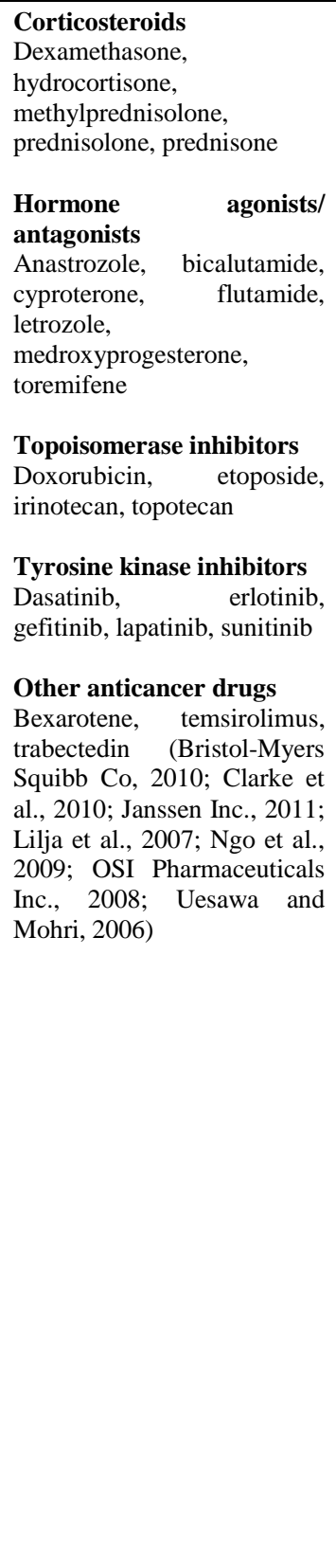 & & & $\begin{array}{l}\text { reduced in } 50 \text { mg decrements if } \\
\text { a dose reduction is necessary. } \\
\text { (b) Ixabepilone: A } 20 \% \text { dose } \\
\text { reduction is generally } \\
\text { recommended in the event of } \\
\text { hematological (e.g. reduced } \\
\text { neutrophil and platelet counts, } \\
\text { febrile neutropenia) and } \\
\text { non-hematological toxicities } \\
\text { (e.g. Grade } 2 \text { or } 3 \text { neuropathy, } \\
\text { any other non-neuropathic Grade } \\
3 \text { toxicities). If toxicities occur, } \\
\text { treatment should be delayed to } \\
\text { allow recovery. If toxicities } \\
\text { recur, an additional } 20 \% \text { dose } \\
\text { reduction should be made. For } \\
\text { severe Grade } 3 \text { neuropathy } \\
\text { lasting } \geq 7 \text { days or any Grade } 4 \\
\text { toxicities, treatment should be } \\
\text { discontinued. } \\
\text { (c) Trabectedin: A dose } \\
\text { reduction to } 1.2 \text { mg/m }{ }^{2} \text { must be } \\
\text { carried out for subsequent } \\
\text { cycles, if any of the following } \\
\text { occur: } \\
- \text { Neutropenia lasting for more } \\
\text { than } 5 \text { days or associated with } \\
\text { fever or infection } \\
- \text { Thrombocytopenia } \\
- \text { Increase of bilirubin to above } \\
\text { upper limit of normal (ULN) } \\
\text { and/or alkaline phosphatase } \\
\text { more than } 2.5 \times \text { ULN } \\
- \\
\text { aminotransferases of more than } \\
2.5 \times \text { ULN that has not } \\
\text { recovered by day } 21 \text { to } \\
- \text { Any other grade } 3 \text { or } 4 \text { adverse } \\
\text { reactions (e.g. nausea, vomiting, } \\
\text { fatigue) } \\
\text { Once a dose has been reduced, } \\
\text { dose escalation in the subsequent } \\
\text { cycles is not recommended. If } \\
\text { any of these toxicities reappear } \\
\text { in subsequent cycles in a patient } \\
\text { exhibiting clinical benefit, the } \\
\text { dose may be further reduced to } 1 \\
\text { mg/m }{ }^{2} \text {. If further dose reductions } \\
\text { are necessary, treatment } \\
\text { discontinuation should be } \\
\text { considered. }\end{array}$ \\
\hline Huachansu & 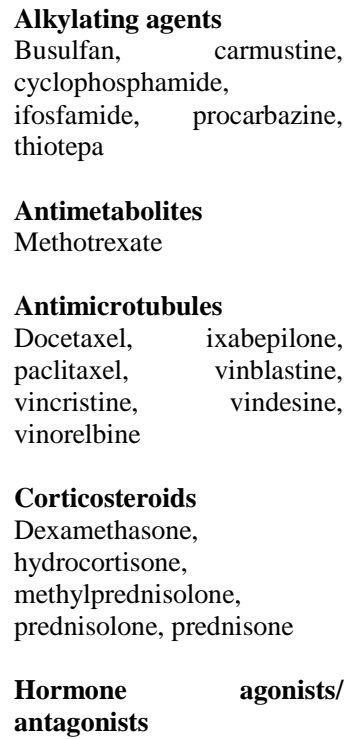 & $\begin{array}{l}\text { Increased plasma ACD } \\
\text { levels due to inhibition of } \\
\text { CYP3A4 by huachansu. }\end{array}$ & $\begin{array}{l}\text { Bufalin (a constituent of } \\
\text { huachansu) modestly inhibited } \\
\text { CYP3A4 both in vitro and in } \\
\text { vivo. Additionally, significant } \\
\text { increases in areas under the } \\
\text { concentration-time curves and } \\
\text { half-lives, as well as decreases } \\
\text { in clearance and formation of } \\
\text { metabolites, were observed } \\
\text { after administration of } \\
\text { midazolam in Wistar rats. }\end{array}$ & $\begin{array}{l}\text { Caution is advised. Plasma ACD } \\
\text { levels should be monitored in } \\
\text { patients concurrently taking } \\
\text { huachansu and dosage } \\
\text { adjustments carried out where } \\
\text { appropriate. Clinicians should } \\
\text { consult a registered herbalist, } \\
\text { naturopath and/or TCM } \\
\text { practitioner for alternative } \\
\text { non-interacting herbs. } \\
\text { In addition, the following should } \\
\text { be taken into account with these } \\
\text { ACDs: } \\
\text { (a) Erlotinib: Doses should be } \\
\text { reduced in } 50 \text { mg decrements if } \\
\text { a dose reduction is necessary. } \\
\text { (b) Ixabepilone: A 20\% dose } \\
\text { reduction is generally } \\
\text { recommended in the event of } \\
\text { hematological (e.g. reduced } \\
\text { neutrophil and platelet counts, } \\
\text { febrile neutropenia) and }\end{array}$ \\
\hline
\end{tabular}




\begin{tabular}{|c|c|c|c|c|}
\hline & $\begin{array}{l}\text { Anastrozole, bicalutamide, } \\
\text { cyproterone, exemestane, } \\
\text { flutamide, fulvestrant, } \\
\text { letrozole, } \\
\text { medroxyprogesterone, } \\
\text { norethisterone, tamoxifen, } \\
\text { toremifene } \\
\text { Topoisomerase inhibitors } \\
\text { Doxorubicin, etoposide, } \\
\text { irinotecan, topotecan } \\
\text { Tyrosine kinase inhibitors } \\
\text { Bortezomib, dasatinib, } \\
\text { erlotinib, gefitinib, imatinib, } \\
\text { lapatinib, sorafenib, sunitinib } \\
\text { Other anticancer drugs } \\
\text { Bexarotene, temsirolimus, } \\
\text { trabectedin (Bristol-Myers } \\
\text { Squibb Co, 2010; Janssen } \\
\text { Inc., 2011; Li et al., 2009; } \\
\text { OSI Pharmaceuticals Inc., } \\
\text { 2008) }\end{array}$ & & & $\begin{array}{l}\text { non-hematological toxicities } \\
\text { (e.g. Grade } 2 \text { or } 3 \text { neuropathy, } \\
\text { any other non-neuropathic Grade } \\
3 \text { toxicities). If toxicities occur, } \\
\text { treatment should be delayed to } \\
\text { allow recovery. If toxicities } \\
\text { recur, an additional } 20 \% \text { dose } \\
\text { reduction should be made. For } \\
\text { severe Grade } 3 \text { neuropathy } \\
\text { lasting } \geq 7 \text { days or any Grade } 4 \\
\text { toxicities, treatment should be } \\
\text { discontinued. } \\
\text { (c) Trabectedin: A dose } \\
\text { reduction to } 1.2 \text { mg/m }{ }^{2} \text { must be } \\
\text { carried out for subsequent } \\
\text { cycles, if any of the following } \\
\text { occur: } \\
- \text { Neutropenia lasting for more } \\
\text { than } 5 \text { days or associated with } \\
\text { fever or infection } \\
- \text { Thrombocytopenia } \\
- \text { Increase of bilirubin to above } \\
\text { upper limit of normal (ULN) } \\
\text { and/or alkaline phosphatase } \\
\text { more than } 2.5 \times \text { ULN } \\
-\quad \text { Increase of liver } \\
\text { aminotransferases to more than } \\
2.5 \text { ULN that has not } \\
\text { recovered by day } 21 \\
- \text { Any other grade } 3 \text { or } 4 \text { adverse } \\
\text { reactions (e.g. nausea, vomiting, } \\
\text { fatigue) } \\
\text { Once a dose has been reduced, } \\
\text { dose escalation in the subsequent } \\
\text { cycles is not recommended. If } \\
\text { any of these toxicities reappear } \\
\text { in subsequent cycles in a patient } \\
\text { exhibiting clinical benefit, the } \\
\text { dose may be further reduced to } 1 \\
\text { mg/m }{ }^{2} \text {. If further dose reductions } \\
\text { are necessary, treatment } \\
\text { discontinuation should be } \\
\text { considered. }\end{array}$ \\
\hline Melatonin & $\begin{array}{l}\text { Corticosteroids } \\
\text { (dexamethasone, } \\
\text { hydrocortisone, } \\
\text { methylprednisolone, } \\
\text { prednisolone, prednisone) } \\
\text { (Haldar et al., 2004; Jellin } \\
\text { and Gregory, 2007; Lissoni } \\
\text { et al., 1999; Lissoni et al., } \\
\text { 1993; Lissoni et al., 1997) }\end{array}$ & $\begin{array}{l}\text { The immunostimulatory } \\
\text { effects of melatonin may } \\
\text { interfere with the } \\
\text { immunosuppressive } \\
\text { activity of corticosteroids. }\end{array}$ & $\begin{array}{l}\text { Animal studies have shown } \\
\text { that melatonin reverses the } \\
\text { immunosuppressive activity of } \\
\text { dexamethasone. Small clinical } \\
\text { studies have also shown that } \\
\text { myelosuppression occurred } \\
\text { less frequently in patients } \\
\text { concurrently on melatonin and } \\
\text { chemotherapy. However, the } \\
\text { immunostimulatory effects of } \\
\text { melatonin occurred only in the } \\
\text { presence of interleukin-2, } \\
\text { which led to increases in the } \\
\text { numbers of lymphocytes, } \\
\text { natural killer cells, } \\
\text { CD25-positive cells and } \\
\text { eosinophils. }\end{array}$ & $\begin{array}{l}\text { Concurrent use of corticosteroids } \\
\text { and melatonin should be } \\
\text { avoided. However, if avoidance } \\
\text { is not possible, monitoring for } \\
\text { altered efficacy and safety of } \\
\text { corticosteroid therapy is } \\
\text { recommended. Clinicians should } \\
\text { consult a registered herbalist, } \\
\text { naturopath and/or TCM } \\
\text { practitioner for alternative } \\
\text { non-interacting herbs. }\end{array}$ \\
\hline $\begin{array}{l}\text { Reishi } \\
\text { mushroom }\end{array}$ & 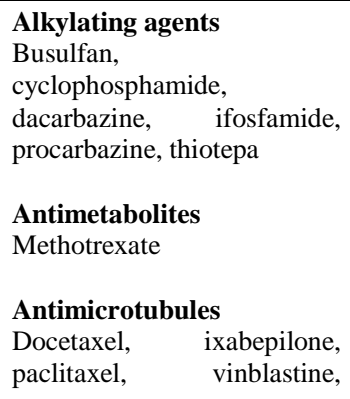 & $\begin{array}{l}\text { Plasma levels of ACDs may } \\
\text { be increased due to } \\
\text { inhibition of CYP1A2, 2E1 } \\
\text { and/or 3A by reishi } \\
\text { mushroom. }\end{array}$ & $\begin{array}{lr}\text { Ganoderma } & \text { lucidum } \\
\text { polysaccharide } & \text { (GLPS), a } \\
\text { major active constituent of } \\
\text { reishi } \\
\text { dose-dependently inhibited } \\
\text { CYP1A2, 2E1 and 3A in vitro. }\end{array}$ & $\begin{array}{l}\text { Caution is advised. Patients } \\
\text { taking these agents together } \\
\text { should be monitored for } \\
\text { increased plasma levels and } \\
\text { altered pharmacological effects } \\
\text { of the ACDs. Dosage } \\
\text { adjustments should be carried } \\
\text { out where appropriate. } \\
\text { Clinicians should consult a } \\
\text { registered herbalist, naturopath } \\
\text { and/or TCM practitioner for } \\
\text { alternative non-interacting herbs. }\end{array}$ \\
\hline
\end{tabular}




\begin{tabular}{|c|c|c|c|c|}
\hline & 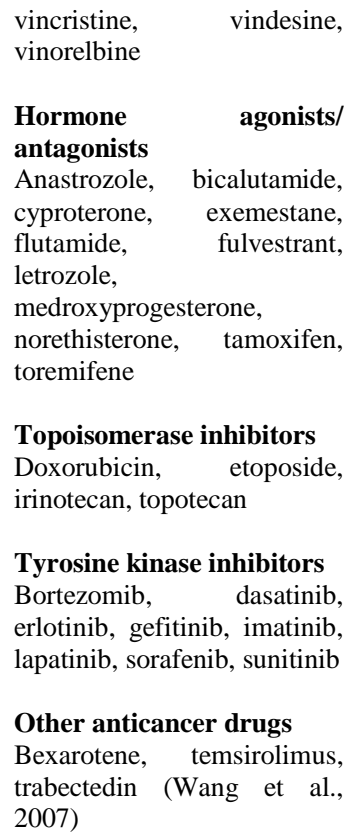 & & & \\
\hline $\begin{array}{l}\text { Reishi } \\
\text { mushroom }\end{array}$ & $\begin{array}{l}\text { Corticosteroids } \\
\text { Dexamethasone, } \\
\text { hydrocortisone, } \\
\text { methylprednisolone, } \\
\text { prednisolone, prednisone } \\
\text { (Ahmadi and Riazipour, } \\
\text { 2007; Cao and Lin, 2003; } \\
\text { Chen et al., 2004; Gao et al., } \\
\text { 2003a; Gao et al., 2002; Gao } \\
\text { et al., 2003b; Gao et al., } \\
\text { 2002; Hsu et al., 2002; Ji et } \\
\text { al., 2007; Lin et al., 2006; } \\
\text { Mao et al., 1999; Ulbricht et } \\
\text { al., 2010; Wang et al., 1997) }\end{array}$ & $\begin{array}{l}\text { Plasma levels of the } \\
\text { corticosteroids may be } \\
\text { increased due to inhibition } \\
\text { of CYP3A isozymes by this } \\
\text { herb. Furthermore, the } \\
\text { immunomodulatory effects } \\
\text { of this herb may interfere } \\
\text { with the } \\
\text { immunosuppressive } \\
\text { activity of the } \\
\text { corticosteroids. }\end{array}$ & 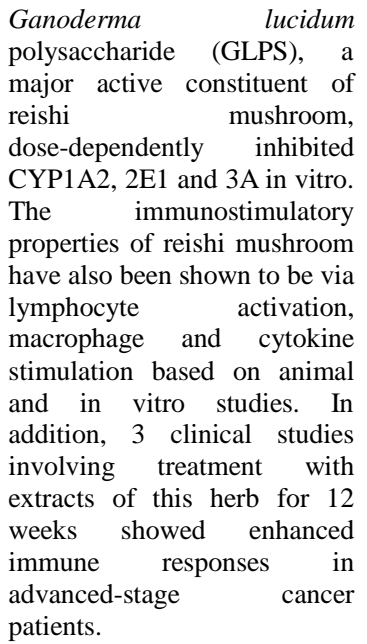 & $\begin{array}{l}\text { Caution is advised during } \\
\text { concurrent use of reishi } \\
\text { mushroom with these agents. } \\
\text { Monitoring for altered efficacy } \\
\text { and safety of corticosteroid } \\
\text { treatment is recommended. } \\
\text { Clinicians should consult a } \\
\text { registered herbalist, naturopath } \\
\text { and/or TCM practitioner for } \\
\text { alternative non-interacting herbs. }\end{array}$ \\
\hline
\end{tabular}

\section{Reishi mushroom}

Reishi mushroom (Ganoderma lucidum), more commonly known as lingzhi, is a herb that is often used by cancer patients for the prevention and/or treatment of disease (Weng and Yen, 2010), or relieving the side-effects of chemotherapy. Its active constituents include the polysaccharide beta-D-glucan and the triterpenes ganoderic and lucidenic acids (Huang, 1999). The triterpenes and polysaccharides inhibit tumor invasion by down-regulating matrix metalloproteinase expression and inhibit tumor metastases by limiting tumor cell adhesion to endothelial cells (Chen et al., 2008; Li et al., 2008), while the latter also has immunostimulation properties via lymphocyte activation, and macrophage and cytokine stimulations (Chen et al., 2004; Gao et al., 2003a; Gao et al., 2002; Gao et al., 2003b; Hsu et al., 2002; Mao et al., 1999; Ulbricht et al., 2010; Wang et al., 1997). Lingzhi can increase the sensitivity of cancer cells to some ACDs, such as cisplatin in ovarian cancer (Zhao et al., 2011). In addition, this herb has antioxidant effects (Wachtel-Galor et al., 2004a; Wachtel-Galor et al., 2004b), relieves chemotherapy-induced nausea and vomiting (Wang et al., 2005), as well as increases the efficacy of radiotherapy in vitro and in animals (Kim et al., 2008).

Ganoderma lucidum polysaccharide (GLPS), a major active constituent, was found to dose-dependently inhibit
CYP1A2, 2E1 and 3A in vitro (Wang et al., 2007). ACDs that are substrates of these isozymes may potentially interact with lingzhi, leading to increased plasma levels of the ACDs (Table 1). Patients concurrently on these agents should be carefully monitored for increased plasma ACD levels, as well as altered pharmacological effects of the ACDs. Dose adjustments should be carried out where necessary according to product information by the manufacturers. Lingzhi can also manifest pharmacokinetic interactions with the corticosteroids through the same DCI mechanism. Furthermore, the immunostimulatory properties of lingzhi can also interfere with the immunosuppressive activities of the corticosteroids. Thus, regular monitoring for altered efficacy and safety of corticosteroid treatment is recommended. Clinicians should consult a registered herbalist, naturopath and/or TCM practitioner for alternative non-interacting herbs.

\section{DISCUSSION}

In TCM practice, herbal combinations are often used to promote desirable interactions (Poon et al., 2010). One of the key principles for TCM prescriptions is the coordination of the seven effects in compatibility (i.e. using alone, mutually 


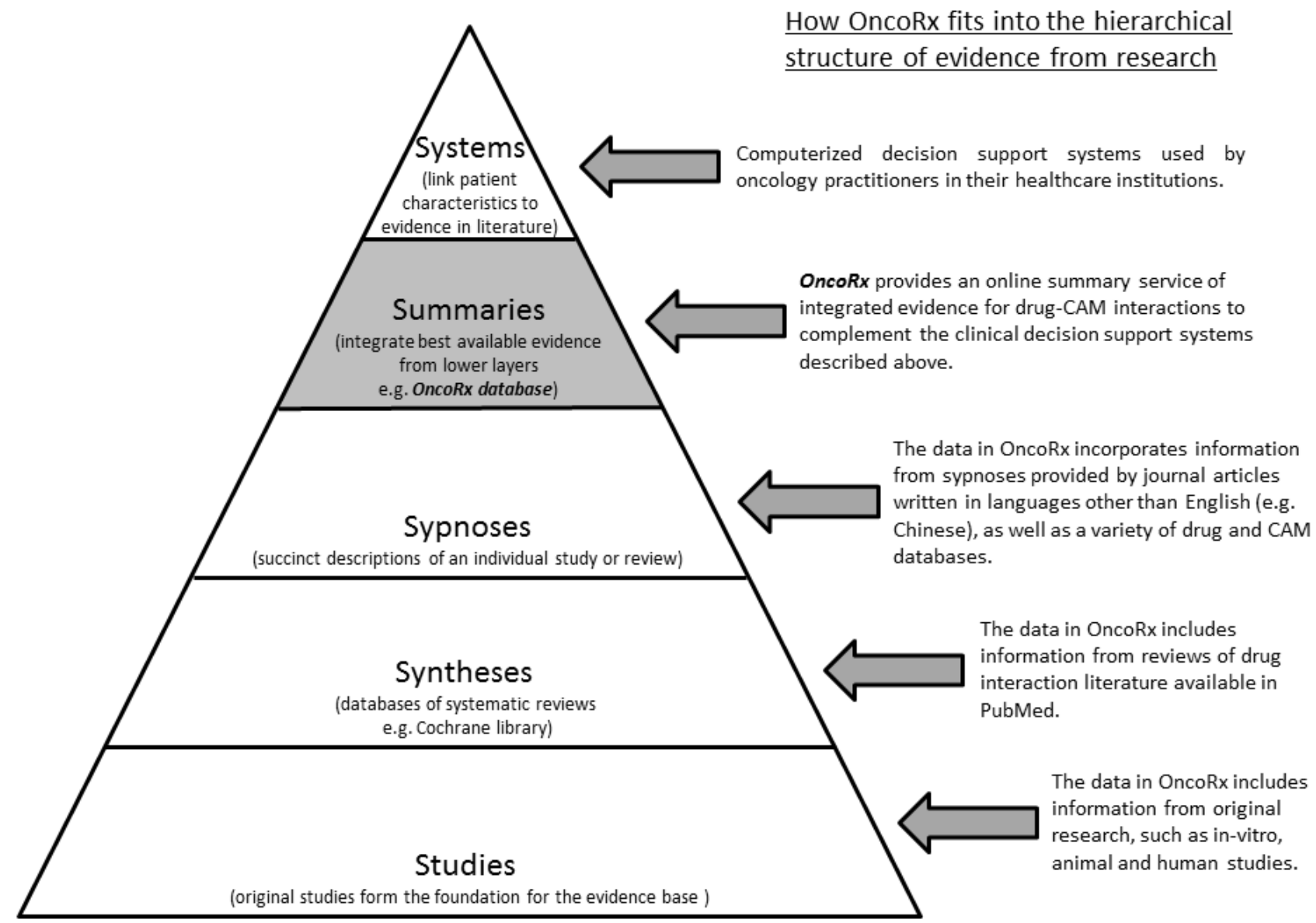

How OncoRx fits into the hierarchical

Computerized decision support systems used by oncology practitioners in their healthcare institutions.

Fig. 4. Haynes " $5 \mathrm{~S}$ " pyramid model showing how OncoRx fits in the research evidence.

reinforcing, assisting, incompatibility, inhibition, detoxifying and antagonism) (Zhou, 2009), whereby the TCM herbs are used in combinations within a prescription to enhance their therapeutic effects, minimize toxicity and side-effects, or produce an effect not seen in the use of single herbal entities (Poon et al., 2010; Sagar and Wong, 2008). Not surprisingly, such combinations are also used in Western medicine to enhance the clinical effects of treatment. In fact, this forms the basis of the multiple-agent chemotherapy cocktails used for cancer therapy (Gao and Wu, 2008; Yap et al., 2008). However, some combinations, more popularly referred to as DCIs, may lead to negative clinical outcomes (e.g. decreasing the effectiveness of therapy and/or manifesting toxicities/ side-effects). These outcomes are the ones that are of major concern in the oncology practice.

It is known that many cancer patients consume CAMs for cancer treatment and supportive care. This is especially true for Asian countries. For example, $45 \%$ of Japanese and $61 \%$ of Taiwanese patients with cancer use CAMs concurrently with their cancer therapies (Chang and Li, 2004; Hyodo et al., 2005). In the Taiwanese population, it was found that TCMs were the most common form of CAM, followed by Western-style health products (Chang and $\mathrm{Li}, 2004)$. In the Singaporean population, $\sim 55-76 \%$ of cancer patients consume CAMs on top of their cancer therapies (Chow et al., 2010; Lim et al., 2005), with the oncologists being unaware of this behavior in $86 \%$ of the cases (Chow et al., 2010). Furthermore, many patients do not want to discuss their CAM use with their healthcare providers for fear of clinician indifference or opposition to their use of CAMs, or a negative response from them (Tasaki et al., 2002). However, clinicians need to know when their patients consume CAMs concurrently with anticancer therapies, so that the potential for
DCIs can be minimized. As such, they need to have adequate information and the appropriate knowledge to discuss various options that are available for their patients, so that the patients are better informed to participate in the management of their own conditions. This paper has demonstrated the potential of CAMs to interact with cancer therapy through the DCIs of 5 common CAMs identified by users of the OncoRx database. Even though majority of the DCIs are theoretical in nature, it is still relevant for practitioners to know that such interactions may exist, so that they can make well-informed decisions with regards to the therapeutic management of their patients.

In this day and age where cyber-technologies are prevalent, many healthcare applications tapping on WiFi or $3 \mathrm{G}$ networks have sprung up in response to the popularity of mobile devices (e.g. Blackberry, Android phones, iPhone) and tablets (e.g. iPad, Samsung Galaxy Tab). It is imperative that drug information databases provide accurate data about CAMs that is evidence-based to clinicians on-the-go, since undesirable consequences may result from cancer patients obtaining erroneous information on the internet or misinterpreting generalized information that is not tailored to their needs (Yap et al., 2009a). OncoRx was designed with the clinician end-users in mind. Responding to feedback from users of this database, priority was given to the 5 CAMs described here as a first update to the CAM module of the database (Yap et al., 2010c). The design principles of this database followed the "Four Pharmaco-cybernetic Maxims" for developing pharmaceutical tools, in relation to quality, quantity, relationship and manner (Yap et al., 2009c); and developers of digital healthcare tools are encouraged to follow these principles as well. The "relationship" principle describes the pertinent issue regarding the kinds of DCI data that are relevant 
for clinicians to know. We had previously sought the opinions of pharmacy practitioners regarding the drug interaction parameters that were essential for a drug information resource to be relevant in their daily practices (Yap et al., 2010a). Our results showed that the top 3 parameters were the mechanism and severity of the interaction, and the presence of a management plan. Since the main target audiences of OncoRx are clinicians and healthcare practitioners, we ensured that these 3 parameters would be shown to users for any searched interactions.

Even though most of the interactions in OncoRx are either theoretical or extrapolated from in vitro and animal studies, the DCI information provided follows the "quality" principle by ensuring that it is evidence-based (i.e. from published literature, other established databases known by clinicians, and package information from drug manufacturers). Although one may argue that these DCIs may not be clinically-relevant since they are not from clinical studies, but the ethical issue of carrying out DCI studies in humans, which defies the Hippocratic Oath to do no harm, has to be taken into consideration. It is important for users of digital healthcare tools, such as OncoRx, to realize that the information provided by these tools is generally meant to complement, and not replace, the expertise and clinical judgment of healthcare practitioners. These tools are potential avenues whereby clinicians can tap on to learn about the possibility of such DCIs occurring and their postulated interaction mechanisms, so that they can clarify their doubts regarding the DCIs and better manage their patients' chemotherapies.

The "quantity" maxim states that the information provided to users of a drug database must be adequate so that they know enough to minimize the likelihood of drug-related problems, in this case-drug-CAM interactions. As such, the data provided by OncoRx is categorized under relevant headings with short, concise summaries to inform clinician users at the point of patient care (Table 1). In addition, the data in OncoRx follows the "manner" principle because effort is made to present the drug-, CAM- and DCI-related information in an appropriate manner that avoids ambiguity and misinterpretation by its users. Bearing in mind that OncoRx is targeted towards clinicians, even though a fair amount of medical and scientific jargon is presented to its users (Figs. 2 and 3), the information provided can be easily understood by the majority of healthcare practitioners in general practices. Besides the top 3 parameters identified by the pharmacy practitioners described previously, a summary of the evidence with appropriate citations and hyperlinks are also incorporated in the database, so that clinicians can gain an overall picture regarding the DCIs, yet gives them an option to go further into the literature if more details are required.

Following the "5S" pyramid model of evidence from research proposed by Haynes (Haynes, 2006), OncoRx fits into the "summaries" level of the hierarchical structure, whereby clinicians can complement the DCI information provided by this database with that of decision support systems to better manage the pharmacotherapies of their patients (Fig. 4). Its data comprises of information from a variety of sypnoses, syntheses and original studies, thus making it a comprehensive database for oncology drug interactions. As an online passive decision support service that aims to provide good quality DCI data to oncology practitioners, details of the methodology for collating and compiling the relevant data have also been explicitly published (Yap et al., 2010c). Furthermore, an ongoing effort is being made by its developers to ensure that its drug interaction content and key references are peer-reviewed to ensure that its quality is of an acceptable standard (Yap et al., 2010b). A new feature that reflects the date of the DCI update has also been recently incorporated. It is intended that the database be updated annually once it is able to detect a substantial amount of DCIs.

Haynes identified from his model several limitations that are especially pertinent as one goes higher up the pyramid (Haynes, 2006). Resources higher up the hierarchy tend to be less readily available. This trend is a result of the high costs of maintaining large and comprehensive systems and/or applications, which generally leads to the costs being passed along to consumers. OncoRx is one of the few drug databases catered specifically towards chemotherapy drug interactions. It was originally created as a free online resource, available at http://bit.ly/cancerRx, as a proof-of-concept to detect clinically-relevant oncology interactions with single-agent and multiple-agent chemotherapies. Since its conception, it has been recognized as a first-of-its-kind to aid in improving the pharmaceutical care of cancer patients (Fua et al., 2011; Poon, 2011). Next, sypnoses and syntheses that are generated on the same topic may provide conflicting results. These conflicts can be resolved by considering the original studies. OncoRx attempts to resolve this issue by including a summary of the conflicting data together with the relevant citations for clinicians so that they are aware of these disagreements during the pharmacotherapeutic management of their patients, and they can search deeper into the literature if needed.

As with most electronic services providing evidence-based information, the compilation and processing of published literature for the OncoRx database takes time and is manpower intensive. The database is currently maintained by its creator who is dual-trained in pharmacy and cybermedicine. The motivation for maintaining OncoRx (on a voluntary basis) is to provide unbiased DCI information for practical use by clinicians dealing with cancer patients. Therefore, content updates and troubleshooting of usability issues are not as fast and efficient as commercial databases managed by large companies. Furthermore, as a database that caters towards an international audience, OncoRx is not able to provide specific management recommendations unless they are recommended by authors of the original studies and/or the pharmaceutical manufacturers, since clinical practices in different countries and institutions may differ. There is also no guarantee that patients may not have unique characteristics that may warrant tailoring of the management plans. Despite these limitations, it is the hope of its creator that the database will expand with time to include DCIs with more CAMs, so that it will become a more comprehensive and clinically useful resource for oncology clinicians and CAM practitioners.

\section{CONCLUSION}

This is the first major update on the CAM module of the OncoRx database since its conception. The potential for CAMs to interact with ACDs has been demonstrated though the DCIs described in this update. In addition, this paper uses this database as a case study for developers to design digital healthcare tools and/or applications according to the "Four Pharmaco-cybernetic Maxims" of quality, quantity, relationship and manner. As a drug information resource that provides evidence-based DCI information for healthcare professionals, this paper also positions OncoRx in the " $5 \mathrm{~S}$ " hierarchy of research evidence, so that they can make the best out of the information from this database as a complement to their existing resources for ACD-CAM interactions.

\section{ACKNOWLEDGEMENTS}

2012 / Volume 2 / Issue 2 / e18 
The authors would like to thank Mr. Enyi Kuo, Ms. Xiu Hui Low, Mr. Teck Ian Chong and Mr. Cheng Shang See for updating and verifying the DCI information in the OncoRx database, as well as updating its user interface.

\section{CONFLICT OF INTEREST}

The authors have declared no conflict of interest directly relevant to the study.

\section{REFERENCES}

Ahmadi K, Riazipour M. Effect of Ganoderma lucidum on cytokine release by peritoneal macrophages. Iran $\mathrm{J}$ Immunol. 2007;4:220-226.

Baker L, Wagner TH, Singer S, Bundorf MK. Use of the internet and e-mail for health care information: results from a national survey. JAMA. 2003;289:2400-2406.

Belardinelli R, Mucaj A, Lacalaprice F, Solenghi M, Seddaiu G, Principi F, Tiano L, Littarru GP. Coenzyme Q10 and exercise training in chronic heart failure. Eur Heart J. 2006;27:2675-2681.

Boles RG, Lovett-Barr MR, Preston A, Li BU, Adams K. Treatment of cyclic vomiting syndrome with co-enzyme Q10 and amitriptyline, a retrospective study. BMC Neurol. 2010;10:10

Bristol-Myers Squibb Co. Ixempra (ixabepilone) for injection [product information]. Princeton, NJ; 2010.

British Medical Association, Pharmaceutical Society of Great Britain. British National Formulary. 53 ${ }^{\text {rd }}$ Ed (London, UK: BMJ Publishing Group Ltd \& RPS Publishing), 2007.

Brzezinski A. Melatonin in humans. N Engl J Med. 1997;336:186-195.

Cao LZ, Lin ZB. Comparison of the effects of polysaccharides from wood-cultured and bag-cultured Ganoderma lucidum on murine spleen lymphocyte proliferation in vitro. Yao Xue Xue Bao. 2003;38:92-97.

Caroleo MC, Frasca D, Nisticó G, Doria G. Melatonin as immunomodulator in immunodeficient mice. Immunopharmacology. 1992;23:81-89.

Chan A, Yap KY-L, Tan SH, Low XH. Efficacy of antiemetics in patients receiving XELOX - A single-centre, prospective study. EJC supplements. 2011;9:17.

Chang L-C, Li I-C. Patterns of complementary therapy use by homebound cancer patients in Taiwan. Appl Nurs Res. 2004;17:41-47.

Chen HS, Tsai YF, Lin S, Lin CC, Khoo KH, Lin CH, Wong $\mathrm{CH}$. Studies on the immuno-modulating and anti-tumor activities of Ganoderma lucidum (Reishi) polysaccharides. Bioorg Med Chem. 2004;12:5595-5601.

Chen NH, Liu JW, Zhong JJ. Ganoderic acid Me inhibits tumor invasion through down-regulating matrix metalloproteinases

TANG / www.e-tang.org
2/9 gene expression. J Pharmacol Sci. 2008;108:212-216.

Chow WH, Chang P, Lee SC, Wong A, Shen HM, Verkooijen HM. Complementary and alternative medicine among Singapore cancer patients. Ann Acad Med Singapore. 2010;39:129-135.

Clarke SJ, McLachlan AJ, Brown D, Carbonara S, Kissane R. Beyond conventional cancer treatments: The use of complementary therapies during cancer treatment: Implications for clinicians. In When Cancer Crosses Disciplines: A Physician's Handbook, Robotin M, Olver I, Girgis A eds. (London, UK: Imperial College Press), pp. 285-316, 2010.

Combs AB, Choe JY, Truong DH, Folkers K. Reduction by coenzyme Q10 of the acute toxicity of adriamycin in mice. Res Commun Chem Pathol Pharmacol. 1977;18:565-568.

Conklin KA. Coenzyme q10 for prevention of anthracycline-induced cardiotoxicity. Integr Cancer Ther. 2005;4:110-130.

DiGianni LM, Garber JE, Winer EP. Complementary and alternative medicine use among women with breast cancer. J Clin Oncol. 2002;20:34s-38s.

e-MS Inc. TCM Assistant. Available at: http://www. tcmassistant. com/index.html (accessed on $10^{\text {th }}$ January 2011).

Ferguson PJ, Kurowska E, Freeman DJ, Chambers AF, Koropatnick DJ. A flavonoid fraction from cranberry extract inhibits proliferation of human tumor cell lines. J Nutr. 2004;134:1529-1535.

Ferguson PJ, Kurowska EM, Freeman DJ, Chambers AF, Koropatnick J. In vivo inhibition of growth of human tumor lines by flavonoid fractions from cranberry extract. Nutr Cancer. 2006;56:86-94.

Fua LN, Beh J, Sen VA. Oncology drug database greatly benefits elderly cancer patients. NUS Knowledge Enterprise. 2011;11:6.

Gao L, Wu X. Comparison of traditional Chinese medicine with Western medicine cancer therapy. Chinese J Clin Oncol. 2008;5:231-234.

Gao Y, Dai X, Chen G, Ye J, Zhou S. A randomized, placebo-controlled, multicenter study of Ganoderma lucidum (W.Curt.:Fr.) Lloyd (Aphyllophoromycetideae) polysaccharides (Ganopoly) in patients with advanced lung cancer. Int J Med Mushrooms. 2003a;5:49-62.

Gao Y, Zhou S, Chen G, Dai X, Ye J. A phase I/II study of a Ganoderma lucidum (Curt.: Fr.) P. Karst. extract (Ganopofy) in patients with advanced cancer. Int $\mathrm{J}$ Med Mushrooms. 2002;4:21-28.

Gao Y, Zhou S, Jiang W, Huang M, Dai X. Effects of ganopoly (a Ganoderma lucidum polysaccharide extract) on the immune functions in advanced-stage cancer patients. Immunol Invest. 2003b;32:201-215.

Gerstner Jr. LV. Memorial Sloan-Kettering Cancer Center cancer information (about herbs, botanicals and other products) Available at: http://www.mskcc.org/mskcc/html/11570.cfm (accessed on $10^{\text {th }}$ January 2011).

2012 / Volume 2 / Issue 2 / e18 
González A, Alvarez-García V, Martínez-Campa C, Mediavilla MD, Alonso-González C, Sánchez-Barceló EJ, Cos S. In vivo inhibition of the estrogen sulfatase enzyme and growth of DMBA-induced mammary tumors by melatonin. Curr Cancer Drug Targets. 2010;10:279-286.

Grant P. Warfarin and cranberry juice: an interaction? J Heart Valve Dis. 2004;13:25-26.

Greenberg S, Frishman WH. Co-enzyme Q10: a new drug for cardiovascular disease. J Clin Pharmacol. 1990;30:596-608.

Greenblatt DJ, von Moltke LL, Perloff ES, Luo Y, Harmatz JS, Zinny MA. Interaction of flurbiprofen with cranberry juice, grape juice, tea, and fluconazole: in vitro and clinical studies. Clin Pharmacol Ther. 2006;79:125-133.

Griffiths AP, Beddall A, Pegler S. Fatal haemopericardium and gastrointestinal haemorrhage due to possible interaction of cranberry juice with warfarin. J R Soc Promot Health. 2008;128:324-326.

Thomson Healthcare. Physicians' Desk Reference (PDR) for Herbal Medicines. Gruenwald J, Brendler T, Jaenicke C eds. $4^{\text {th }}$ Ed. (Stamford, USA: Thomson Reuters), 2007.

Haldar C, Rai S, Singh R. Melatonin blocks dexamethasone-induced immunosuppression in a seasonally breeding rodent Indian palm squirrel, Funambulus pennanti. Steroids. 2004;69:367-377.

Hamann GL, Campbell JD, George CM. Warfarin-cranberry juice interaction. Ann Pharmacother. 2011;45:e17.

Han H-B, Chen J-Y, Yuan Y, Liang D-M, Zhang Y. The effect of cinobufacin combined with 5-FU on inhibiting proliferation and inducting apoptosis of human gastric carcinoma cells. Chinese J Gen Surgery. 2006;9:4.

Hashimoto S, Jing Y, Kawazoe N, Masuda Y, Nakajo S, Yoshida T, Kuroiwa Y, Nakaya K. Bufalin reduces the level of topoisomerase II in human leukemia cells and affects the cytotoxicity of anticancer drugs. Leuk Res. 1997;21:875-883.

Haynes RB. Of studies, syntheses, synopses, summaries, and systems: the "5S" evolution of information services for evidence-based healthcare decisions. Evid Based Med. 2006;11:162-164.

Hsiao WL, Liu L. The role of traditional Chinese herbal medicines in cancer therapy - from TCM theory to mechanistic insights. Planta Med. 2010;76:1118-1131.

Hsu MJ, Lee SS, Lin WW. Polysaccharide purified from Ganoderma lucidum inhibits spontaneous and Fas-mediated apoptosis in human neutrophils through activation of the phosphatidylinositol 3 kinase/Akt signaling pathway. J Leukoc Biol. 2002;72:207-216.

Huang KC. The Pharmacology of Chinese Herbs. $2^{\text {nd }}$ ed. (Boca Raton, USA: CRC Press), 1999.

Hyodo I, Amano N, Eguchi K, Narabayashi M, Imanishi J, Hirai M, Nakano T, Takashima S. Nationwide survey on complementary and alternative medicine in cancer patients in Japan. J Clin Oncol. 2005;23:2645-2654.
Janssen Inc. Yondelis (trabectedin) for injection [product information]. Toronto, Ontario; 2011.

Jellin JM, Gregory PJ. Natural Medicines Comprehensive Database. $10^{\text {th }}$ Ed (Stockton, New Zealand: Therapeutic Research Faculty), 2007.

Ji Z, Tang Q, Zhang J, Yang Y, Jia W, Pan Y. Immunomodulation of RAW264.7 macrophages by GLIS, a proteopolysaccharide from Ganoderma lucidum. J Ethnopharmacol. 2007;112:445-450.

Jiang Y, Zhang Y, Luan J, Duan H, Zhang F, Yagasaki K, Zhang G. Effects of bufalin on the proliferation of human lung cancer cells and its molecular mechanisms of action. Cytotechnol. 2010;62:573-583.

Kim KC, Jun HJ, Kim JS, Kim IG. Enhancement of radiation response with combined Ganoderma lucidum and Duchesnea chrysantha extracts in human leukemia HL-60 cells. Int J Mol Med. 2008;21:489-498.

Kummervold PE, Chronaki CE, Lausen B, Prokosch H-U, Rasmussen J, Santana S, Staniszewski A, Wangberg SC. EHealth trends in Europe 2005-2007: a population-based survey. J Med Internet Res. 2008;10:e42.

Lacy CF, Armstrong LL, Goldman MP, Lance LL. Drug Information Handbook with International Trade Names Index. $15^{\text {th }}$ ed. (Hudson, USA: Lexi-comp Inc.), 2007-2008.

Leja-Szpak A, Jaworek J, Pierzchalski P, Reiter RJ. Melatonin induces pro-apoptotic signaling pathway in human pancreatic carcinoma cells (PANC-1). J Pineal Res. 2010;49:248-255.

Li HY, Xu W, Zhang X, Zhang WD, Hu LW. Bufalin inhibits CYP3A4 activity in vitro and in vivo. Acta Pharmacol Sin. 2009;30:646-652.

Li YB, Wang R, Wu HL, Li YH, Zhong LJ, Yu HM, Li XJ. Serum amyloid A mediates the inhibitory effect of Ganoderma lucidum polysaccharides on tumor cell adhesion to endothelial cells. Oncol Rep. 2008;20:549-556.

Lilja JJ, Backman JT, Neuvonen PJ. Effects of daily ingestion of cranberry juice on the pharmacokinetics of warfarin, tizanidine, and midazolam - probes of CYP2C9, CYP1A2, and CYP3A4. Clin Pharmacol Ther. 2007;81:833-839.

Lim MK, Sadarangani P, Chan HL, Heng JY. Complementary and alternative medicine use in multiracial Singapore. Complement Ther Med. 2005;13:16-24.

Lin KI, Kao YY, Kuo HK, Yang WB, Chou A, Lin HH, Yu AL, Wong $\mathrm{CH}$. Reishi polysaccharides induce immunoglobulin production through the TLR4/TLR2-mediated induction of transcription factor Blimp-1. J Biol Chem. 2006;281: 24111-24123.

Lissoni P. Is there a role for melatonin in supportive care? Support Care Cancer. 2002;10:110-116.

Lissoni P, Barni S, Mandala M, Ardizzoia A, Paolorossi F, Vaghi M, Longarini R, Malugani F, Tancini G. Decreased toxicity and increased efficacy of cancer chemotherapy using the pineal hormone melatonin in metastatic solid tumour patients with poor clinical status. Eur J Cancer. 
1999;35:1688-1692.

Lissoni P, Barni S, Tancini G, Rovelli F, Ardizzoia A, Conti A, Maestroni GJ. A study of the mechanisms involved in the immunostimulatory action of the pineal hormone in cancer patients. Oncology. 1993;50:399-402.

Lissoni P, Tancini G, Barni S, Paolorossi F, Ardizzoia A, Conti A, Maestroni G. Treatment of cancer chemotherapy-induced toxicity with the pineal hormone melatonin. Support Care Cancer. 1997;5:126-129.

Macek C. East meets West to balance immunologic yin and yang. JAMA. 1984;251:433-435, 439.

Mansky PJ, Wallerstedt DB. Complementary medicine in palliative care and cancer symptom management. Cancer J. 2006;12:425-431.

Mao T, van De Water J, Keem CL, Stern JS, Hackman R, Gershwin ME. Two mushrooms, Grifola frondosa and Ganoderma lucidum, can stimulate cytokine gene expression and proliferation in human $\mathrm{T}$ lymphocytes. Int $\mathrm{J}$ Immunother. 1999;15:13-22.

Martín-Renedo J, Mauriz JL, Jorquera F, Ruiz-Andrés O, González P, González-Gallego J. Melatonin induces cell cycle arrest and apoptosis in hepatocarcinoma HepG2 cell line. J Pineal Res. 2008;45:532-540.

Memorial Sloan-Kettering Cancer Center. Coenzyme Q10. Available at: http://www.mskcc.org/mskcc/html/69186.cfm (accessed on $12^{\text {th }}$ September 2011).

Meng Z, Yang P, Shen Y, Bei W, Zhang Y, Ge Y, Newman RA, Cohen L, Liu L, Thornton B, et al. Pilot study of huachansu in patients with hepatocellular carcinoma, nonsmall-cell lung cancer, or pancreatic cancer. Cancer. 2009;115:5309-5318.

Nahleh Z, Tabbara IA. Complementary and alternative medicine in breast cancer patients. Palliat Support Care. 2003;1:267-273.

National Institutes of Health. Medline Plus Herbs and Supplements. Available at: http://www.nlm.nih.gov/ medlineplus/druginfo/herb_All.html (accessed on $12^{\text {th }}$ September 2011).

National Institutes of Health, National Center for Complementary and Alternative Medicine. Health topics A-Z. Available at: http://nccam.nih.gov/health/atoz.htm (accessed on $12^{\text {th }}$ September 2011).

Neto CC, Amoroso JW, Liberty AM. Anticancer activities of cranberry phytochemicals: an update. Mol Nutr Food Res. 2008;52:S18-27.

Ngo N, Yan ZX, Graf TN, Carrizosa DR, Kashuba ADM, Dees EC, Oberlies NH, Paine MF. Identification of a cranberry juice product that inhibits enteric CYP3A-mediated first-pass metabolism in humans. Drug Metab Dispos. 2009;37:514-522.

Oldendick R, Coker AL, Wieland D, Raymond JI, Probst JC, Schell BJ, Stoskopf CH. Population-based survey of complementary and alternative medicine usage, patient satisfaction, and physician involvement. South Carolina Complementary Medicine Program Baseline Research Team.
South Med J. 2000;93:375-381.

Ortíz-López L, Morales-Mulia S, Ramírez-Rodríguez G, Benítez-King G. ROCK-regulated cytoskeletal dynamics participate in the inhibitory effect of melatonin on cancer cell migration. J Pineal Res. 2009;46:15-21.

OSI Pharmaceuticals Inc. Tarceva (erlotinib hydrochloride) tablets [product information]. Melville, NY; 2008.

Paeng CH, Sprague M, Jackevicius CA. Interaction between warfarin and cranberry juice. Clin Ther. 2007;29:1730-1735.

Park JW, Hwang MS, Suh SI, Baek WK. Melatonin down-regulates HIF-1 alpha expression through inhibition of protein translation in prostate cancer cells. J Pineal Res. 2009;46:415-421.

Poon $\mathrm{CH}$. Cancer drug database may protect patients. The Straits Times 2011;Sect. Home:B2. Available at: http://www. straitstimes.com/Singapore/Story/STIStory_707047.html (acces sed on $30^{\text {th }}$ August 2011).

Poon S, Poon J, Chan K, Loy C, Zhou X, Zhang R, Liu B, Kwan P, Sze D, Gao J. Analysis of synergistic and antagonistic effects of TCM: Cases on diabetes and insomnia: Paper presented at: IEEE International Conference on Bioinformatics and Biomedicine Workshops; 18 December, 2010; Hong Kong.

Qi F, Li A, Inagaki Y, Kokudo N, Tamura S, Nakata M, Tang W. Antitumor activity of extracts and compounds from the skin of the toad Bufo bufo gargarizans Cantor. Int Immunopharmacol. 2011;11:342-349.

Qin TJ, Zhao XH, Yun J, Zhang LX, Ruan ZP, Pan BR. Efficacy and safety of gemcitabine-oxaliplatin combined with huachansu in patients with advanced gallbladder carcinoma. World J Gastroenterol. 2008;14:5210-5216.

Raymond C. TCM Materia Medica (Chinese Herbal Database). Available at: http://www.tcmbasics.com/materiamedica.htm (accessed on $12^{\text {th }}$ September 2011).

Rootdown LLC. Rootdown.us - grow together (v2.187.423.57). Available at: http://www.rootdown.us/. (accessed on $08^{\text {th }}$ August 2009).

Rosenfeldt FL, Haas SJ, Krum H, Hadj A, Ng K, Leong JY, Watts GF. Coenzyme Q10 in the treatment of hypertension: a meta-analysis of the clinical trials. J Hum Hypertens. 2007;21:297-306.

Roxane Laboratories Inc. Cyclophosphamide tablets USP [product information]. Columbus, OH; 2007.

Sagar SM, Wong RK. Chinese medicine and biomodulation in cancer patients - Part one. Curr Oncol. 2008;15:42-48.

Seeram NP, Adams LS, Hardy ML, Heber D. Total cranberry extract versus its phytochemical constituents: antiproliferative and synergistic effects against human tumor cell lines. J Agric Food Chem. 2004;52:2512-2517.

Shim M. Connecting internet use with gaps in cancer knowledge. Health Commun. 2008;23:448-461.

Shinozawa S, Gomita Y, Araki Y. Tissue concentration of 
doxorubicin (adriamycin) in mouse pretreated with alpha-tocopherol or coenzyme Q10. Acta Med Okayama. 1991;45:195-199.

Shinozawa S, Kawasaki H, Gomita Y. Effect of biological membrane stabilizing drugs (coenzyme Q10, dextran sulfate and reduced glutathione) on adriamycin (doxorubicin)-induced toxicity and microsomal lipid peroxidation in mice. Gan To Kagaku Ryoho. 1996;23:93-98.

Sparreboom A, Cox MC, Acharya MR, Figg WD. Herbal remedies in the United States: potential adverse interactions with anticancer agents. J Clin Oncol. 2004;22:2489-2503.

Stothers L. A randomized trial to evaluate effectiveness and cost effectiveness of naturopathic cranberry products as prophylaxis against urinary tract infection in women. Can $\mathbf{J}$ Urol. 2002;9:1558-1562.

Sun J, Hai Liu R. Cranberry phytochemical extracts induce cell cycle arrest and apoptosis in human MCF-7 breast cancer cells. Cancer Lett. 2006;241:124-134.

Suvarna R, Pirmohamed M, Henderson L. Possible interaction between warfarin and cranberry juice. BMJ. 2003;327:1454.

Takai N, Ueda T, Nishida M, Nasu K, Narahara H. Bufalin induces growth inhibition, cell cycle arrest and apoptosis in human endometrial and ovarian cancer cells. Int J Mol Med. 2008;21:637-643.

Tan KY, Liu CB, Chen AH, Ding YJ, Jin HY, Seow-Choen F. The role of traditional Chinese medicine in colorectal cancer treatment. Tech Coloproctol. 2008;12:1-6; discussion 6.

Tasaki K, Maskarinec G, Shumay DM, Tatsumura Y, Kakai H. Communication between physicians and cancer patients about complementary and alternative medicine: exploring patients' perspectives. Psychooncol. 2002;11:212-220.

Tascilar M, de Jong FA, Verweij J, Mathijssen RHJ. Complementary and alternative medicine during cancer treatment: beyond innocence. Oncologist. 2006;11:732-741.

Thomson Healthcare. Micromedex ${ }^{\circledR}$ Healthcare Series [internet database]. Available at: http://www.micromedex.com (accessed on $03^{\text {th }}$ February 2011).

Trubiani O, Recchioni R, Moroni F, Pizzicannella J, Caputi S, Di Primio R. Melatonin provokes cell death in human B-lymphoma cells by mitochondrial-dependent apoptotic pathway activation. J Pineal Res. 2005;39:425-431.

Tsinghua Tongfang Knowledge Network Technology Co. Ltd. China National Knowledge Infrastructure (CNKI). Available at: http://en.cnki.com.cn/ (accessed on $12^{\text {th }}$ September 2011).

Tsubaki K, Horiuchi A, Kitani T, Taniguchi N, Masaoka T, Shibata H, Yonezawa T, Tsubakio T, Kawagoe H, Shinohara Y, et al. Investigation of the preventive effect of CoQ10 against the side-effects of anthracycline antineoplastic agents. Gan To Kagaku Ryoho. 1984;11:1420-1427.

Uesawa Y, Mohri K. Effects of cranberry juice on nifedipine pharmacokinetics in rats. J Pharm Pharmacol. 2006;58: 1067-1072.
Ulbricht C, Abrams TR, Bent S, Boon H, Costa D, Dacey C, Guilford J, Giese N, Serrano JMG, Hackman DA, et al. Reishi mushroom (Ganoderma lucidum): Systematic review by the natural standard research collaboration. J Soc Integr Oncol. 2010;8:148-159.

Ushijima K, Koshimizu T-a, Fujimura A. The inhibitory effect of cranberry juice on phenytoin metabolism by human liver microsomes. Jap J Clin Pharmacol Ther. 2009a;40:59-64.

Ushijima K, Tsuruoka S, Tsuda H, Hasegawa G, Obi Y, Kaneda T, Takahashi M, Maekawa T, Sasaki T, Koshimizu TA, et al. Cranberry juice suppressed the diclofenac metabolism by human liver microsomes, but not in healthy human subjects. $\mathrm{Br}$ J Clin Pharmacol. 2009b;68:194-200.

Wachtel-Galor S, Szeto YT, Tomlinson B, Benzie IF. Ganoderma lucidum ('Lingzhi'); acute and short-term biomarker response to supplementation. Int J Food Sci Nutr. 2004a;55:75-83.

Wachtel-Galor S, Tomlinson B, Benzie IF. Ganoderma lucidum ("Lingzhi"), a Chinese medicinal mushroom: biomarker responses in a controlled human supplementation study. Br J Nutr. 2004b;91:263-269.

Wang CZ, Basila D, Aung HH, Mehendale SR, Chang WT, McEntee E, Guan X, Yuan CS. Effects of ganoderma lucidum extract on chemotherapy-induced nausea and vomiting in a rat model. Am J Chin Med. 2005;33:807-815.

Wang SY, Hsu ML, Hsu HC, Tzeng CH, Lee SS, Shiao MS, Ho $\mathrm{CK}$. The anti-tumor effect of Ganoderma lucidum is mediated by cytokines released from activated macrophages and $\mathrm{T}$ lymphocytes. Int J Cancer. 1997;70:699-705.

Wang X, Zhao X, Li D, Lou YQ, Lin ZB, Zhang GL. Effects of Ganoderma lucidum polysaccharide on CYP2E1, CYP1A2 and CYP3A activities in BCG-immune hepatic injury in rats. Biol Pharm Bull. 2007;30:1702-1706.

Welch JM, Forster K. Probable elevation in international normalized ratio from cranberry juice. J Pharm Technol. 2007;23:104-107.

Weng CJ, Yen GC. The in vitro and in vivo experimental evidences disclose the chemopreventive effects of Ganoderma lucidum on cancer invasion and metastasis. Clin Exp Metastasis. 2010;27:361-369.

White JD. The National Cancer Institute's perspective and agenda for promoting awareness and research on alternative therapies for cancer. J Altern Complement Med. 2002;8: 545-550.

Wong R, Sagar CM, Sagar SM. Integration of Chinese medicine into supportive cancer care: a modern role for an ancient tradition. Cancer Treat Rev. 2001;27:235-246.

Wu W-Y, Chai X-S, Liu W-S. Synergistic anti-cancer effects and mechanisms of huachansu plus vinorelbine on Lewis lung cancer cell in mice. China Oncol. 2004;4:18.

Xu X-Q. Study on the effects of Cinobufacin combined with taxol on murine S180 tumor in vivo. Strait Pharmaceutical J. 2009;2:8 
Yang P, Chan D, Vijjeswarapu M, Cartwright C, Cohen L, Meng ZQ, Liu LM, Newman RA. Anti-proliferative activity of Huachansu, a Bufo toad skin extract, against human malignant melanoma cells: Paper presented at: American Association for Cancer Research, 2006.

Yang P, Zhu X, Chan D, Cartwright C, Meng ZQ, Liu LM, Cohen L, Newman RA. Huachansu inhibits growth of human pancreatic cancer Panc-1 and BxPC3 xenograft tumors: Paper presented at: 99th American Association for Cancer Research (AACR) Annual Meeting, San Diego, CA, 2008.

Yap KY-L, Chan A, Chui WK. Improving pharmaceutical care in oncology by pharmacoinformatics: the evolving role of informatics and the internet for drug therapy. Lancet Oncol. 2009a;10:1011-1019.

Yap KY-L, Chan A, Chui WK. Opinions on drug interaction sources in anticancer treatments and parameters for an oncology-specific database by pharmacy practitioners in Asia. Health Services Insights. 2010a;3:1-12.

Yap KY-L, Chen YZ, Chui WK, Chan A. Oncoinformatics for the healthcare professional: oncology databases and blogs. Internet J Oncol. 2009b;6:1-22.

Yap KY-L, Chuang X, Lee AJM, Lee RZ, Lim L, Lim JJ, Nimesha R. Pharmaco-cybernetics as an interactive component of pharma-culture: empowering drug knowledge through user-, experience- and activity-centered designs. Int J Comput Sci Issues. 2009c;3:1-13.

Yap KY-L, See CS, Chan A. Clinically-relevant chemotherapy interactions with complementary and alternative medicines in patients with cancer. Recent Pat Food Nutr Agric. 2010b;2:12-55.

Yap KY, Chui WK, Chan A. Drug interactions between chemotherapeutic regimens and antiepileptics. Clin Ther. 2008;30:1385-1407.

Yap KY, Kuo EY, Lee JJ, Chui WK, Chan A. An onco-informatics database for anticancer drug interactions with complementary and alternative medicines used in cancer treatment and supportive care: an overview of the OncoRx project. Support Care Cancer. 2010c;18:883-891.
Yates JS, Mustian K, Morrow GR, Gillies LJ, Padmanaban D, Atkins JN, Issell B, Kirshner JJ, Colman LK. Prevalence of complementary and alternative medicine use in cancer patients during treatment. Support Care Cancer. 2005;13:806-811.

Yu CH, Kan SF, Pu HF, Jea Chien E, Wang PS. Apoptotic signaling in bufalin- and cinobufagin-treated androgen-dependent and -independent human prostate cancer cells. Cancer Sci. 2008;99:2467-2476.

Yun HR, Yoo HS, Shin DY, Hong SH, Kim JH, Cho CK, Choi YH. Apoptosis induction of human lung carcinoma cells by Chan Su (Venenum Bufonis) through activation of caspases. J Acupunct Meridian Stud. 2009;2:210-217.

Zhang L, Li J-M, Wang Y, Shen Z-X. Apoptosis of monocytic leukemia cells induced by etoposide with the cooperation of cinobufacini. Journal of Internal Medicine Concepts and Practice. 2007;2:12.

Zhang L, Ma J, Pan K, Go VL, Chen J, You WC. Efficacy of cranberry juice on Helicobacter pylori infection: a double-blind randomized placebo-controlled trial. Helicobacter. 2005;10:139-145.

Zhao S, Ye G, Fu G, Cheng JX, Yang BB, Peng C. Ganoderma lucidum exerts anti-tumor effects on ovarian cancer cells and enhances their sensitivity to cisplatin. Int $\mathrm{J}$ Oncol. 2011;38:1319-1327.

Zhou J. New understanding of the basic theory of traditional Chinese medicine. Chin J Integr Med. 2009;15:7-12.

Ziebland S, Chapple A, Dumelow C, Evans J, Prinjha S, Rozmovits L. How the internet affects patients' experience of cancer: a qualitative study. BMJ. 2004;328:564-569.

Zikria J, Goldman R, Ansell J. Cranberry juice and warfarin: when bad publicity trumps science. Am J Med. 2010;123: 384-392.

Zupancic D, Vidmar G, Jezernik K. Melatonin prevents the development of hyperplastic urothelium induced by repeated doses of cyclophosphamide. Virchows Arch. 2009;454:657-666. 